\title{
АКТУАЛЬНІ ПИТАННЯ ПІДСЛІДНОСТІ КРИМІНАЛЬНИХ ПРОВАДЖЕНЬ
}

Січко С. 0 .

Стаття присвячена дослідженню дискусійних серед науковців окремих питань поняття та сутності підслідності кримінальних проваджень. Досліджуються основні складові частини правового інституту підслідності кримінальних проваджень, їх риси та властивості. Аналізуються висловлені вченими підходи щодо вдосконалення правил визначення підслідності кримінальних проваджень, усунення наявних у кримінальному процесуальному законодавстві прогалин і суперечностей. Вивчаються проблемні питання шляхів удосконалення законодавчого регулювання питань визначення підслідності кримінальних проваджень.

Ключові слова: кримінальне провадження, загальні положення, підслідність, органи досудового розслідування.

Статья посвящена исследованию дискуссионных среди ученых отдельных вопросов понятия и сущности подследственности уголовных производств. Исследуются основные составные части правового института подслед ственности уголовных производств, их черты и свойства. Анализируются высказанные учеными подходы по совершенствованию правил определения подследственности уголовных производств, устранение существующих в уголовном процессуальном законодательстве пробелов и противоречий. Изучаются проблемные вопросы путей совершенствования законодательного регулирования вопросов определения подследственности уголовных производств.

Ключевые слова: уголовное производство, общие положения, подследственность, органы досудебного расследования.

The article is devoted to the research of the discussion among the scientists and practitioners about the concept and essence of the investigation of criminal proceedings, as well as the competence of the bodies of pre-trial investigation. Among scholars in the field of criminal process, there are differences in views on understanding the nature of the investigation, the separate problems of differentiating the competence of various organs of pre-trial investigation are resolved ambiguously. The article deals with the main components of the legal institute of investigation of criminal proceedings, their features and properties. The reform of the pre-trial investigation bodies, as well as the initiation of investigating facilities in the newly created pre-trial investigation bodies, is accompanied by a number of difficulties and conflicts. Attention is drawn to the signs of criminal proceedings, which determines their jurisdiction to a certain body of pre-trial investigation. The issue of selection of types of investigation, including in view of the latest changes and amendments to the existing criminal procedural legislation, was studied. The scientists' approaches to improving the rules for determining the scope of criminal proceedings, and the elimination of gaps and contradictions in the criminal procedural law are analyzed. There is a need for normative consolidation of the rules of investigation exclusively in the CPC of Ukraine and emphasizes the inadmissibility of consolidating such provisions in other legislative acts. Problematic issues of ways of improving the legislative regulation of issues of territorial jurisdiction of criminal proceedings are explored, in

Січко С. О., 2019 particular in situations that provoke controversy disputes, with a view to preventing them in the future. On the basis of the study, proposals were made to introduce changes and additions to the current CPC of Ukraine.

Key words: criminal proceedings, terms, conscience, bodies of pre-trial investigation.

Постановка проблеми та іï актуальність. Актуальність дослідження підслідності кримінальних проваджень зумовлена тим, що в науці кримінального процесу $є$ чисельні розбіжності у підходах до розуміння сутності такої правової категорії взагалі та шляхів вирішення окремих проблем розмежування компетенції органів досудового розслідування зокрема. Процеси реформування вже чинних органів досудового розслідування, а тим більше утворення і початок діяльності слідчих апаратів у новостворених органах досудового розслідування супроводжуються низкою непорозумінь і конфліктів, окремі з яких набули широкого розголосу в засобах масової інформації, мережі Інтернет, що аж ніяк не сприяє досягненню завдань кримінального судочинства та утвердженню авторитету органів охорони правопорядку та їх посадових осіб. Наявність такого роду проблем, у свою чергу, ускладнює розроблення науково обґрунтованих пропозицій для вдосконалення чинного кримінального процесуального законодавства та подолання низки негативних явищ, які виникають у діяльності органів досудового розслідування та прокуратури.

Аналіз останніх досліджень і публікацій. Дослідженню різних аспектів правового регулювання підслідності кримінальних проваджень приділили увагу у своїх працях такі вчені, як І.В. Гловюк, В.К. Волошина, В.О. Гринюк, Ю.І. Кицан, А.А. Омаров, В.В. Павловський, А.А. Патик, М.А. Погорецький та інші. Підслідність кримінальних проваджень була предметом дисертацій Ю.І. Кицана [1] і А.А. Омарова [2]. Окремі питання підслідності в контексті загальних положень досудового розслідування досліджувалися в дисертаціях В.К. Волошиної [3] та В.В. Павловського [4].

Метою статті $\epsilon$ розроблення науково обґрунтованих пропозицій щодо удосконалення чинного кримінального процесуального законодавства в частині регулювання підслідності кримінальних проваджень.

Виклад основного матеріалу. Згідно зі ст. $19 \mathrm{Koн}-$ ституції України органи державної влади та органи місцевого самоврядування, їх посадові особи зобов'язані діяти лише на підставі, в межах повноважень та у спосіб, що передбачені Конституцією та законами України. Зазначене конституційне положення повинно бути покладено в основу визначення компетенції усіх державних органів та їх посадових осіб, зокрема і органів досудового розслідування. Одним із ключових елементів системи компетенції органів досудового розслідування $\epsilon$ визначення їх предмета відання. М.С. Горо- 
децька цілком слушно зауважує, що саме по собі вірне визначення предмета відання окремого суб'єкта в законодавстві $\epsilon$ запорукою ефективного кримінального провадження. Правильне визначення предмета відання суб'єкта згодом під час правозастосовної діяльності стане основою здійснення провадження «законним» суб'єктом, що становить умову забезпечення права людини на справедливий суд [5, с. 184]. На нашу думку, до цього варто додати, що здійснення провадження саме належним суб'єктом $є$ важливою умовою допустимості отриманих доказів у кримінальному провадженні. На жаль, не $\epsilon$ унікальними у правозастосовній практиці ситуації, коли зібрані в кримінальному провадженні докази визнавалися судом недопустимими саме через порушення встановленим кримінальним процесуальним законодавством правил підслідності. Наприклад, суд встановив, що стороною обвинувачення не доведено правомірності проведення слідчих дій військовим прокурором та слідчим військової прокуратури Чернівецького гарнізону в рамках досудового розсліӘування цього кримінального провадження, яке, на думку суду, не було підслідне та піднаглядне військовій прокуратурі Чернівецького гарнізону, з 5 вересня 2016 року до 14 вересня 2016 року, тобто до моменту визначення підслідності заступником прокурора в установленому законом порядку. 3 чієї ж підстави суд визнає недопустимим доказом протокол огляду місця події від 8 вересня 2016 року, який складений слідчим військової прокуратури Чернівецького гарнізону. Суд визнає недопустимим доказом покази понятих, оскільки такі особи були присутні як поняті підчас проведення неповноважним суб'єктом слідчоі діï. За результатами судового розгляду суд ухвалив виправдувальний вирок [6]. Отже, можна констатувати, що правильне визначення підслідності кримінального провадження має важливе значення як для реалізації прав та законних інтересів особи, так і для реалізації завдань кримінального судочинства в частині притягнення винних до відповідальності.

Наявні у правозастосовній практиці проблеми під час визначення підслідності кримінальних проваджень навряд чи можливо пояснити виключно суб' єктивними чинниками, а саме неправильним застосуванням кримінального процесуального законодавства окремими посадовими особами. Чимало питань виникає також щодо якості чинного кримінального процесуального законодавства, наявності у ньому окремих прогалин і суперечностей. Насамперед варто звернути увагу на ту обставину, що і в доктрині кримінального процесу, і в законодавстві одночасно вживаються терміни «підслідність», «юрисдикція», «компетенція», «повноваження». При цьому чинний КПК України не містить нормативного визначення зазначених понять. У науці кримінального процесу приділено чимало уваги дослідженню проблематики підслідності і вироблено кілька підходів до розуміння цього правового явища. Якщо узагальнити висловлені вченими позиції, то можна констатувати наявність двох основних підходів до визначення поняття підслідності: у першому випадку підслідність визначають через ознаки кримінального провадження (кримінальної справи) за якими воно належить до відання певного органу досудового розслідування, у другому випадку - підслідність визначають як складову частину компетенції органу досудового розслідування.
До прикладу, М.С. Строгович визначав підслідність як властивість справи, відповідно до якої вона належить до відання того чи іншого слідчого або категорії слідчих [7, с. 41]. В.В. Вапнярчук визначає підслідність як сукупність встановлених кримінальним процесуальним законом ознак кримінального провадження, відповідно до яких вона належить до відання певного органу досудового розслідування [8, с. 276]. М.А. Погорецький, В.О. Гринюк визначають підслідність як сукупність встановлених законом ознак кримінального провадження, залежно від яких законодавець відносить його до компетенції того чи іншого органу досудового розслідування [9, с. 62]. Отже, як ключову, домінуючу властивість підслідності згадані автори виділяють саме ознаки кримінального провадження.

3.3. Зінатуллін, М.С. Салахов, Л.Д. Чулюкін під підслідністю пропонують розуміти систему встановлених законом повноважень органів розслідування щодо ведення певного кола кримінальних справ залежно від ï юридичних властивостей із метою досягнення чіткості та оперативності під час провадження попереднього (досудового) розслідування [10, с. 14]. Ю.І. Кицан пропонує визначати підслідність як частину компетенції органів досудового розслідування, яка полягає у праві й обов' язку розслідувати певну категорію кримінальних справ [11, с. 161]. Отже, згадані дослідники розглядають підслідність як складову частину компетенції орану досудового розслідування. Певною мірою компромісною можна вважати позицію А.А. Омарова, який стверджує, що зміст інституту підслідності складає система приписів, якими встановлюються правила визначення органу, що має здійснювати досудове розслідування кримінального правопорушення [12, с. 22], у свою чергу, інститут підслідності має розглядатися як сукупність кримінальних процесуальних норм, що містять правила, дотримання яких дає змогу визначити орган, який має здійснювати досудове розслідування кримінального правопорушення [12, с. 22, 28]. Підсумовуючи викладене, вважаємо, що під час визначення досліджуваного поняття насамперед слід виходити з того, що підслідність $€$ складовою частиною компетенції орану досудового розслідування, юридичним засобом окреслення предмету відання відповідного органу. Власне ознаки кримінального провадження $є$ лише юридичним засобом для визначення підслідності і в підсумку - компетенції - відповідного органу досудового розслідування. Законодавець в окремих випадках ототожнює терміни «підслідність» $\mathbf{i}$ «компетенція». Зокрема, відповідно до частини другої ст. 218 кПК України у разі, якщо слідчому із заяви, повідомлення або інших джерел стало відомо про обставини, які можуть свідчити про кримінальне правопорушення, розслідування якого не належить до його компетенції, він проводить розслідування доти, доки прокурор не визначить іншу підслідність $[13$, с. $61-62]$.

Серед учених у галузі кримінального процесу тривають дискусії щодо виділення видів (ознак, правил) підслідності. Одразу варто зауважити, що основний масив позицій щодо виділення тих чи інших видів підслідності було розроблено науковцями на основі дореформеного кримінального процесуального законодавства. У зв'язку з набранням чинності КПК України 2012 року, а також численних змін до цього нормативно-правового акту, наявні підходи потребують перегляду та уточ- 
нення. Тому вважаємо за доцільне зосередити увагу на позиціях учених, які досліджували підслідність на основі КПК України 2012 року. На думку Ю.І Кицана, треба виділяти шість видів підслідності: 1) предметну (родову); 2) територіальну; 3) персональну; 4) альтернативну; 5) за зв'язком справ 6) за визначенням прокурора (виключна, імперативна, універсальна) [14, с. 8]. А.А. Омаров виділяє шість основних видів підслідності: 1) предметну, 2) персональну, 3) підслідність за зв'язком проваджень, 4) альтернативну, 5) універсальну, 6) територіальну підслідність [12, с. 86]. В.В. Вапнярчук виділяє предметну (родову), персональну, предметно-персональну, за зв'язком проваджень, альтернативну, територіальну, імперативну, виключну підслідність [8, с. 276]. У літературі практично відсутні обґрунтовані заперечення щодо виділення таких видів підслідні як предметна, персональна, за зв'язком проваджень. Однак виділення нині такого виду підслідності, як альтернативна, викликає певні сумніви, оскільки у початковій редакції КПК України вона була відсутня; згодом Законом України від 7 жовтня 2014 р. ст. 216 було доповнено частиною шостою, яка передбачала, що «у кримінальних провадженнях щодо злочинів, передбачених ст. ст. 209, 258, 2581, 258 2 258 $38^{3}, 258^{4}, 258^{5}$, 261 Кримінального кодексу України, досудове розслідування здійснюється слідчим того органу, який розпочав досудове розслідування» [15]. Ці правові положення були скасовані Законом України 12 лютого 2015 р. [16].

Потребавиділення відносно новоговидупідслідності, а саме предметно-персональної зумовлена створенням та початком діяльності Національного антикорупційного бюро України (далі - НАБУ). У літературі зазначалося, що під час визначення предметної підслідності законодавцем враховуються принципи організації, умови та специфіка діяльності кожного з органів досудового розслідування, оскільки від правильного визначення можливостей того чи іншого органу під час розслідування певного виду злочинів залежить ефективність такої діяльності [17, с. 30-33]. П. 1 ч. 5. ст. 216 КПК України визначено, що детективи Національного антикорупційного бюро України здійснюють досудове розслідування злочинів, передбачених ст. ст. 191, 206-2, 209, 210, 211, 354 (стосовно працівників юридичних осіб публічного права), 364, 366-1, 368, 368-2, 369, 369-2, 410 КК України. Крім того, п. 3 ч. 5 ст. 216 КПК України передбачає здійснювання розслідування злочинів, передбачених ст. 369, ч. 1 ст. 369-2 КК України, але одночасно встановлюються умови, які належать до персонального виду підслідності (п. 2 ч. 5 ст. 216 КПК України 2012 р.), ознакою предметної підслідності - розміром предмета злочину або завданої ним шкоди (п. 3 ч. 5 ст. 216 КПК України). Варто зауважити, що законодавець, визначаючи підслідність НАБУ, у п. 2 ч. 1 ст. 17 Закону України «Про Національне антикорупційне бюро України» [18] передбачив право НАБУ за рішенням директора Національного бюро, погодженим із прокурором, витребовувати від інших правоохоронних органів оперативно-розшукові справи та кримінальні провадження, що стосуються кримінальних правопорушень, віднесених законом до підслідності Національного бюро, та інших кримінальних правопорушень, які не належать до його підслідності. У зв'язку з цим варто погодитися з позицією М.А. Погорецького і С.Г. Волкотруба, які стверджують, що під час розроблення нового та вдосконалення чинного кримінального процесуального законодавства України варто відмовитися від практики закріплення кримінальних процесуальних норм в інших законодавчих актах України, оскільки такі положення явно суперечать вимогам частини третьої ст. 9 КПК України, яка передбачає, що закони та інші нормативно-правові акти України, положення яких стосуються кримінального провадження, повинні відповідати КПК України, а під час здійснення кримінального провадження не може застосовуватися закон, який суперечить КПК України $[19$, с. 78]. Такий підхід заслуговує на підтримку.

Стосовно таких видів підслідності, як імперативна, або за визначенням прокурора, варто вказати на потребу подальшого вдосконалення чинного кримінального процесуального законодавства для того, що сформулювати чіткі правила для прокурора, керуючись якими він міг визначати підслідність кримінального провадження власним рішенням. Наявний стан справ, коли прокурору надане право своїм рішенням визначити підслідність того чи іншого кримінального провадження будь-якому органу досудового розслідування, навряд чи можна вважати припустимим, особливо у світлі вимог засад верховенства права та правової визначеності.

Відповідно до правил територіальної підслідності кримінальне провадження повинен здійснювати слідчий того органу досудового розслідування, під юрисдикцією якого перебуває місце вчинення кримінального правопорушення (ст. 218 КПК України). Однак якщо місце вчинення кримінального правопорушення невідоме або його вчинено за межами України, місце проведення досудового розслідування визначає відповідний прокурор з урахуванням місця виявлення ознак кримінального правопорушення, місця перебування підозрюваного чи більшості свідків, місця закінчення кримінального правопорушення або настання його наслідків тощо (ч. 2 ст. 218 КПК України).

У літературі можна натрапити на твердження, що у слідчій практиці визначення місця вчинення злочину не зумовлює особливих труднощів у тому разі, коли місце його вчинення і місце настання злочинних наслідків збігаються. Проблеми у вирішенні цих питань виникають тоді, коли такі місця не збігаються, а також під час вчинення злочину у співучасті та в деяких інших випадках, що трактуються різними науковцями неоднозначно [1]. Наприклад, 3.3. Зінатулін, М.С. Салахов, Л.Д. Чулюкін, вважають, якщо не збігається місце вчинення суспільно небезпечних дій (бездіяльності) і їх злочинних наслідків, то місцем вчинення злочину слід вважати те, де були вчинені дії, які призвели до злочинного результату [10, с. 30-31]. А.А. Патик наводить приклади з категорії «чорного» гумору, коли працівники правоохоронних органів, користуючись нагодою відсутності свідків, перетягують труп з одного на інший бік проїжджої частини (на територію обслуговування іншого підрозділу), або відштовхують труп від берега, куди його прибило течією річки, і подібних «сценаріїв» багато [20, с. 155-164]. На нашу думку, якщо невідоме місце вчинення злочину, а так само у разі вчинення триваючих злочинів, досудове розслідування повинен проводити той орган, слідчі якого таке правопорушення виявили.

Висновки. Підсумовуючи та узагальнюючи висловлені думки вчених щодо розуміння сутності підслідності, вважаємо що під час визначення іï поняття слід виходити з розуміння підслідності як складової 
частини компетенції органу досудового розслідування. Отже, підслідність - це сукупність правил, згідно з якими визначається орган досудового розслідування, уповноважений розслідувати конкретне кримінальне провадження. Чинне кримінальне процесуальне законодавство потребує удосконалення, зокрема всі нормативні положення щодо підслідності кримінальних проваджень повинні бути закріплені саме в КПК України і неприпустиме закріплення в інших законодавчих актах положень, які дублюють, доповнюють, а тим більше суперечать положенням КПК України.

\section{Література}

1. Кицан Ю.І. Підслідність кримінальних справ : дис ... канд. юрид. наук : 12.00.09. Київ, 2012. 200 с.

2. Омаров А.А. Інститут підслідності в кримінальному провадженні : дис. ... канд. юрид. наук : 12.00.09. Харків, 2017. 200 c.

3. Волошина В.К. Реалізація галузевих та специфічних принципів кримінального процесу у стадії досудового розслідування : дис. ... канд. юрид. наук : 12.00.09. Одеса, 2010. 236 c.

4. Павловський В.В. Загальні положення досудового розслідування : дис. ... канд. юрид. наук : 12.00.09. Київ, 2016. 246 c.

5. Городецька М.С. Природа та структура предмета відання у кримінальному процесі. Правовий часопис Донбасу. 2018. № 1. С. 183-189.

6. Вирок Кельменецького районного суду Чернівецької області від 12 жовтня 2018 р., судове провадження № 1-кп/717/1/18. URL : http://www.reyestr.court.gov.ua/ Review/77098737.

7. Строгович М.С. Курс советского уголовного процесса : в 2 т. Москва : Наука, 1970. Т. 2. 616 с.

8. Кримінальний процес : підручник / О.В. Капліна, О.Г. Шило, В.М. Трофіменко та ін. / за заг. ред. О.В. Капліної, О.Г. Шило. Харків : Право, 2018. 584 с.

9. Погорецький М.А., Гринюк В.О. Визначення прокурором підслідності кримінального провадження. Вісник кримінального судочинства. 2016. № 3. С. 60-68.

10. Зинатуллин 3.3. Салахов М.С., Чулюкин Л.Д. Подследственность уголовных дел. Казань : Изд-во Казанского ун-та, 1986. С. 30-31.

11. Кицан Ю.І. Розмежування підслідності при порушенні та розслідуванні кримінальних справ. Університетські наукові записки. 2010. № 1. С. 160-163.
Протидія злочинності: проблеми практики та науково-методичне забезпечення

12. Омаров А.А. Інститут підслідності в кримінальному провадженні : дис. ... канд. юрид. наук : 12.00.09. Харків, 2017. 200 c.

13. Погорецький М.А., Гринюк В.О. Визначення прокурором підслідності кримінального провадження. Вісник кримінального судочинства. 2016. № 3. С. 60-68.

14. Кицан Ю.І. Підслідність кримінальних справ: теоретичні засади вдосконалення нормативно-правового регулювання. Часопис Національного університету «Острозька академія». Серія: «Право». 2012. № 2 (6). URL : https://lj.oa.edu.ua/articles/2012/n2/12kyinpr.pdf.

15. Про внесення змін до Кримінального та Кримінального процесуального кодексів України щодо невідворотності покарання за окремі злочини проти основ національної безпеки, громадської безпеки та корупційні злочини : Закон України від 7 жовтня 2014 р. № 1689-VII. Законодавство України. URL : http://zakon0.rada.gov.ua/laws/ show/1689-18.

16. Про внесення змін до Кримінального процесуального кодексу України щодо виконання рекомендацій Європейського Союзу з виконання Україною Плану дій щодо лібералізації Європейським Союзом візового режиму для України стосовно уточнення підслідності органів досудового розслідування : Закон України від 10 листопада 2015 р. № 771-VIII. Законодавство України. URL : http://zakon3.rada.gov.ua/laws/show/771-19.

17. Власова Н.А., Соловьев А.Б., Токарева М.А. Общие условия предварительного расследования : монография. Москва : Юрлитинформ, 2005. 144 с.

18. Про Національне антикорупційне бюро України : Закон України від 14 жовтня 2014 р. № 1698-VII. Законодавство України. URL : https://zakon.rada.gov.ua/laws/ show/1698-18.

19. Погорецький М.А., Волкотруб С.Г. Удосконалення кримінального процесуального законодавства України щодо підслідності органів досудового розслідування. Вісник кримінального судочинства. 2017. №1. С. 72-80.

20. Патик А.А. Підслідність злочинів на досудовому розслідуванні за новим кримінальним процесуальним кодексом України. Науковий вісник Національної академії внутрішніх справ. 2014. № 2. С. 155-164.

Січко С. 0. здобувач кафедри кримінального процесу Національного юридичного університету імені Ярослава Мудрого 